\title{
PERBAIKAN PEMBELAJARAN UNTUK MENINGKATKAN KEMAMPUAN MENYELESAIKAN SOAL CERITA MENGGUNAKAN STRATEGI NUMBER HEAD TOGETHER (NHT)
}

\author{
Maaratus Solikha ${ }^{1)}$, Mohammad Edy Nurtamam ${ }^{2)}$ \\ Jurusan Pendidikan Guru Sekolah Dasar, Universitas Trunojoyo Madura
}

\begin{abstract}
Lack of understanding by completing word problems due to the lack of attention to the students' mathematics courses, methods and strategies used in the classroom is very monotonous. Based on these problems, researchers wanted to examine whether the strategy Number Head Together (NHT) can improve the ability to solve word problems. Class Action Research aims to improve the learning of mathematics subjects completed the fractions word problems so that the students can learn mathematics increased. This study was conducted over two days on 17 and 22 April 2014 at SDN Banyuajuh 05 Kamal. The research subject is class IV consisting of 24 students including 13 sons and 11 daughters who have different backgrounds. This study consisted of two cycles, where each cycle is a step that should be achieved as a measure of mastery learning achievement of students consisting of four stages: planning, implementation, observation, and reflection. After conducting action research can be concluded that the strategy Number Head Together (NHT) can improve the ability to solve word problems Banyuajuh 05 grade IV SDN Kamal. From the analysis it was found that mastery learning students has increased from the first cycle to the second cycle of the first cycle and cycle II 70.83\% 91.67\%.
\end{abstract}

Keyword: ability, story problems, Number Head Together

\footnotetext{
${ }^{1}$ Korespondensi : Maaratus Solikha, Jurusan Pendidikan Guru Sekolah Dasar,Universitas Trunojoyo Madura,email : likakang2@gmail.com

${ }^{2}$ Korespondensi : Mohammad Edy Nurtamam, S. Pd, M. Si, Jurusan Pendidikan Guru Sekolah Dasar,Universitas Trunojoyo Madura, email : edynurtamam@trunojoyo.ac.id
} 


\section{PENDAHULUAN}

Mengajar adalah sebuah proses menyampaikan pengetahuan kepada peserta didik atau murid di sekolah. Jadi syarat utama seseorang dikatakan mengajar bila terdapat satu pihak sebagai pemberi pengetahuan sedangkan pihak lain yang menerima pengetahuan.

Dalam pembelajaran di kelas, kebanyakan anak menyebut pelajaran matematika merupakan pelajaran yang paling sulit. Sehingga pelajaran matematika kurang disukai oleh anakanak. Hal yang sering dijumpai yaitu siswa yang kurang bisa memahami dan mengerjakan soal cerita. Namun jika seorang guru dapat menyampaikan informasi dengan bahasa matematika yang lebih praktis, sistematis dan efisien, maka betapa pentingnya pelajaran matematika dalam kehidupan sehari-hari.

Kenyataan di lapangan yang penulis temukan adalah $60 \%$ siswa kelas IV SDN Banyuajuh 05 Kamal tidak dapat menyelesaikan soal cerita. Kemampuan itu masih sangat rendah berdasarkan hasil belajar siswa pada pelaksanaan tes, dimana nilai dari 24 siswa belum memenuhi ketuntasan kelulusan minimum.

Rendahnya penguasaan dalam menyelesaikan soal cerita disebabkan karena perhatian siswa terhadap mata pelajaran matematika kurang, metode yang digunakan dalam kelas sangat monoton dan selalu di dominasi ceramah, pemberian reward yang minim terhadap siswa yang berhasil, proses belajar mengajar kurang menarik dan membosankan bagi siswa, media pembelajaran yang digunakan terbatas dan kurang menggunakan benda-benda nyata dan motivasi yang digunakan rendah dan sering kurang menarik perhatian siswa sehingga mereka selalu kesulitan dalam menyelesaikan soal cerita.

Berdasarkan hasil observasi pembelajaran ketika penulis melakukan
Penelitian Tindakan Kelas (PTK) di kelas SDN Banyuajuh 05 Kamal, diperoleh suatu gambaran permasalahan di dalam pembelajaran matematika yang kurang diminati oleh siswa dan permasalahan tersebut sangat berpengaruh terhadap hasil belajar siswa. Untuk itu peniliti menentukan pilihan strategi Number Head Together (NHT) sebagai tindakan pemecahan masalah agar siswa ini bisa menyelesaikan soal cerita dengan mudah, sehingga kemampuan dan prestasi belajar matematika siswa dapat meningkat.

Berdasarkan uraian diatas, maka penulis tertarik untuk melakukan suatu Penelitian Tindakan Kelas (PTK) untuk memperbaiki permasalahan di dalam kelas, dengan judul "Perbaikan Pembelajaran untuk Meningkatkan Kemampuan Menyelesaikan Soal Cerita Menggunakan Strategi Number Head Together (NHT) pada Siswa Kelas IV SDN Banyuajuh 05 Kamal". Tujuan Penelitian ini memperbaiki/mengatasi permasalahan menyelesaikan soal cerita pada mata pelajaran matematika, dengan menggunakan model Number Head Together (NHT).

\section{METODE PENELITIAN}

Penelitian ini menggunakan pendekatan kualitatif dengan jenis Penelitian Tindakan Kelas (PTK). Model penelitian tindakan yang digunakan dari Sephen Kemmis atau Mc Taggart yaitu berbentuk spiral dari siklus satu ke siklus berikutnya. Setiap siklus meliputi empat komponen yaitu perencanaan, pelaksanaan tindakan, pengamatan atau observasi, refleksi. ${ }^{1}$

Subjek yang dijadikan sumber data dalam penelitian ini adalah siswa kelas IV SDN Banyuajuh 05 Kamal pada Semester II tahun ajaran 2013/ 2014. Jumlah 
keseluruhan ada 24 siswa yang terdiri dari 13 orang laki-laki dan 11 orang perempuan dengan tingkat karakter dan kemampuan yang berbeda, baik kemampuan ekonomi sosial maupun kemampuan dalam pemikirannya. Penelitian Tindakan Kelas (PTK) ini dilaksanakan di SDN Banyuajuh 05 Kamal yang pelaksanaannya pada tanggal 17 dan 22 April 2014.

Perangkat Perangkat perbaikan pembelajaran yang digunakan dalam penelitian ini yaitu pertama, Rencana Pelaksanaan Pembelajaran (RPP) yang disusun berdasarkan materi pembelajaran. Dalam penelitian ini RPP yang digunakan adalah RPP materi pecahan dengan Strategi Number Head Together (NHT). RPP disusun berdasarkan SK dan KD yang akan diajarkan pada setiap siklus. Kedua, Lembar Kerja Siswa (LKS). Lembar ini disusun untuk tugas yang harus diselesaikan siswa untuk menunjang proses belajarnya untuk mencapai tujuan pembelajarannya. Instrumen ini merupakan penerapan strategi Number Head Together (NHT) dalam kelompok yang digunakan pada setiap siklus. Ketiga, Lembar Tes Formatif digunakan untuk mengetahui hasil belajar siswa sebagai patokan untuk mengukur kemampuan siswa dan ketuntasan belajar siswa dalam menyelesaikan soal cerita pecahan pada setiap siklusnya. Instrumen ini dibuat peneliti sendiri dan dikonsultasikan dengan teman sejawat, soal tes terdiri dari 5 soal cerita. Tes ini dilakukan pada akhir pembelajaran. Dan perangkat yang keempat yaitu materi ajar. Materi ajar ini adalah materi yang akan diberikan atau diajarkan guru kepada siswa. Materi ajar disusun berdasarkan SK dan KD yang akan disampaikan Dalam penelitian ini adalah materi ajar tentang menyelesaikan soal cerita mengenai masalah pecahan.

Teknik pengumpulan data yang digunakan dalam penelitian ini adalah observasi, wawancara, dokumentasi, dan tes. Instrumen penelitian yang digunakan dalam penelitian ini adalah lembar observasi, lembar pedoman wawancara, lembar dokumentasi, dan lembar tes formatif. Instrumen penelitian yang pertama adalah lembar observasi, dalam hal ini, peneliti banyak menggunakan jenis observasi langsung, upaya yang peneliti gunakan adalah untuk menggali data tentang keadaan guru dan anak dalam kelas, sarana dan prasarana, serta Peningkatan Kemampuan Menyelesaikan Soal Cerita Menggunakan Strategi Number Head Together (NHT) Pada Siswa Kelas IV SDN Banyuajuh 05 Kamal.

Instrumen penelitian yang kedua menggunakan lembar pedoman wawancara. Adapun yang akan diwawancarai pada penelitian ini adalah semua yang ada di SDN Banyuajuh 05 Kamal baik guru, maupun siswanya. Wawancara dilakukan sebelum dan sesudah perbaikan pembelajaran agar dapat diketahui secara jelas adanya Peningkatan kemampuan siswa dalam menyelesaikan soal Cerita materi pecahan, dengan menggunakan model Number Head Together (NHT).

Instrumen penelitian yang ketiga adalah dengan menggunakan lembar dokumentasi. Adapun yang dimaksud disini adalah pengambilan data dengan cara mencatat, mencetak dan merekam semua hal yang berhubungan dengan siswa kelas IV SDN Banyuajuh 05 Kamal. Dokumentasi ini dilakukan untuk mengumpulkan hasil belajar siswa maupun foto-foto aktivitas siswa saat kegiatan perbaikan pembelajaran berlangsung.

Instrumen penelitian yang keempat dalam penelitian ini adalah lembar tes formatif. Tes ini digunakan untuk mengetahui perkembangan kemampuan peserta didik dalam mengerjakan soal dan juga untuk mengetahui ketuntasan belajar peserta didik dalam mengerjakan soal 
cerita mata pelajaran matematika dengan materi pecahan. Tes formatif sebanyak 5 soal cerita pada setiap siklus. Tes formatif ini diberikan untuk menganalisa keberhasilan siswa setelah proses pembelajaran setiap siklus. Peneliti menentukan ketuntasan belajar siswa secara individu jika siswa telah memperoleh nilai diatas KKM yaitu $>70$. Dan dalam penelitian ini diharapkan dapat mencapai ketuntasan hasil belajar klasikal atau ketuntasan kelas $(\mathrm{T})>80 \%$.

Penelitian ini akan dilaksanakan selama dua siklus. Namun sebelum melakukan dua siklus tersebut, peneliti melakukan pra-siklus. Pada pra siklus ini, peneliti melakukan pengamatan dan mengambil beberapa data dari SDN Banyuajuh 05 Kamal yang akan dijadikan penelitian seperti RPP, hasil belajar siswa, LKS, dan lembar tes formatif yang digunakan oleh guru kelas.

Seperti yang dikatakan Sephen Kemmis atau Mc Taggart dalam Suharsimi (2009:35) setiap siklus terdiri atas 4 tahapan, yaitu perencanaan, pelaksanaan, observasi, dan refleksi. Perencanaan adalah berisi hal-hal yang direncanakan dan yang disiapkan sebelum melaksanakan pelaksanaan, pelaksanaan adalah melaksanakan dari apa yang sudah direncanakan sebelumnya, observasi adalah pengamatan yang dilakukan selama pelaksanaan berlangsung dan yang terakhir adalah refleksi yang merupakan refleksi dan evaluasi dari pelaksanaan perbaikan pembelajaran yang sudah dilakukan. Hasil refleksi akan dijadikan masukan atau saran untuk perbaikan dalam proses mengajar pada siklus II.

Siklus II dilaksanakan berdasarkan hasil refleksi dari siklus I. Pada Siklus I, peneliti mengharapkan ketuntasan belajar klasikal mencapai > $80 \%$, bila pada Siklus I belum mencapai target yang ditentukan maka target tersebut akan dicapai pada Siklus II, namun apabila ketuntasan belajar klasikal sudah mencapai target pada Siklus I maka peneliti akan tetap melaksanakan Siklus II untuk meningkatkan ketuntasan belajar klasikal pada Siklus I tersebut. Dalam penelitian ini, perbaikan pembelajaran hanya dilakukan hingga siklus II, karena diharapkan hasil yang telah dicapai pada siklus II telah menunjukkan hasil yang maksimal dari kriteria ketentuan belajar yang telah direncanakan.

\section{PEMBAHASAN}

Tabel 1. Perbandingan Ketuntasan Belajar antara Pra Siklus dengan Siklus I

\begin{tabular}{|l|l|l|l|l|l|}
\hline \multirow{2}{*}{ No. } & \multirow{3}{*}{ Ketuntasan } & \multicolumn{4}{|c|}{ Jumlah Siswa } \\
\cline { 3 - 6 } & & \multicolumn{2}{|c|}{ Pra siklus Siklus I } \\
\cline { 3 - 6 } & & Jumlah & Persen & Jumlah & Persen \\
\hline 1. & Tuntas & 10 & $41,67 \%$ & 17 & $70,83 \%$ \\
\hline 2. & Tidak tuntas & 14 & $58,33 \%$ & 7 & $29,17 \%$ \\
\hline & Jumlah & 24 & $100 \%$ & 24 & $100 \%$ \\
\hline
\end{tabular}


Tabel 2. Perbandingan Ketuntasan Belajar antara Siklus I dengan Siklus II

\begin{tabular}{|l|l|c|c|c|c|}
\hline \multirow{2}{*}{ No. } & \multirow{2}{*}{ Ketuntasan } & \multicolumn{3}{|c|}{ Jumlah Siswa } \\
\cline { 3 - 6 } & & \multicolumn{2}{|c|}{ Siklus I } & \multicolumn{2}{c|}{ Siklus II } \\
\cline { 3 - 6 } & & \multirow{2}{*}{ Jumlah } & Persen & Jumlah & Persen \\
\hline 1. & Tuntas & 17 & $70,83 \%$ & 22 & $91,67 \%$ \\
\hline 2. & Tidak tuntas & 7 & $29,17 \%$ & 2 & $8,33 \%$ \\
\hline & Jumlah & 24 & $100 \%$ & 24 & $100 \%$ \\
\hline
\end{tabular}

Berdasarkan hasil pengumpulan data nilai siswa, dari keseluruhan 24 siswa hanya 10 siswa yang tuntas pada pembelajaran Matematika materi Menyelesaikan Soal Cerita Pecahan. Sehingga bila dipresentasikan ketuntasan klasikal pembelajaran Matematika materi Menyelesaikan Soal Cerita Pecahan pada kelas IV SDN Banyuajuh 05 Kamal hanya mencapai 41,67 \% pada Pra Siklus.

Pada siklus I diawali dengan perencanaan. Pada tahap perencanaan dilakukan untuk mempersiapkan beberapa hal yang diperlukan dalam selanjutnya seperti RPP, LKS, lembar tes formatif, dll. Setelah melalui tahap persiapan, peneliti melakukan pelaksanaan perbaikan pembelajaran yang dilakukan pada hari Kamis tanggal 17 April 2014 pukul 08.2009.30 sesuai dengan perangkat pembelajaran yang telah dibuat yaitu menggunakan model Number Head Together (NHT) untuk menyelesaikan soal cerita mengenai pecahan. Dalam pelaksanaan tindakan guru membagi siswa menjadi 4 kelompok dan diberi nomor kepala pada masing-masing siswa di setiap kelompok. Pada tahap pengamatan yang dilakukan oleh guru kemudian membagikan LKS pada masing-masing kelompok untuk di diskusikan jawabannya. Setelah selesai berdiskusi guru memanggil nomor siswa secara acak untuk menyampaikan jawaban kelompok di depan kelas. Pada akhir pembelajaran guru memberi lembar tes

formatif untuk untuk mengetahui hasil belajar siswa sebagai patokan untuk mengukur kemampuan siswa dan ketuntasan belajar siswa dalam Menyelesaikan Soal Cerita Pecahan.

Pada siklus I dapat dilihat adanya pengurangan jumlah siswa yang di bawah KKM. Pada pra siklus jumlah siswa yang dibawah KKM sebanyak 14 siswa dan pada akhir siklus I berkurang menjadi 7 siswa. Nilai rata-rata kelas meningkat menjadi 76,63. Pada siklus I ketuntasan belajar klasikal mencapai 70,83 \% namun belum memenuhi kriteria ketuntasan belajar klasikal yang ditetapkan yaitu 80 $\%$. Belum tercapainya indikator keberhasilan hasil belajar siswa pada siklus I ini dikarenakan siswa yang kurang siap dan kurang memahami aturan main strategi pembelajaran Number Head Together (NHT) yang diterapkan, sehingga guru kesulitan dalam mengelola kelas. Siswa gaduh, kurang memperhatikan petunjuk atau penjelasan dari guru. Oleh karena itu perlu diadakan siklus II.

Siklus II yang dilakukan pada hari selasa tanggal 22 April 2014 pukul 10.2011.30 sesuai dengan perangkat pembelajaran yang telah dibuat berdasarkan hasil refleksi dari siklus I. Tahapan-tahapan yang dilaksanakan hampir sama dengan siklus I akan tetapi pada siklus II guru membagi siswa dalam kelompok kecil. Diharapkan pembelajaran dapat lebih fokus dan guru dapat mengelola kelas dengan baik. Berdasarkan hasil pengamatan dapat dianalisis bahwa ketuntasan belajar sudah memenuhi kriteria ketuntasan belajar yaitu 91,67\%. Pada siklus II dapat dilihat adanya pertambahan jumlah siswa yang di diatas 
KKM. Pada siklus I jumlah siswa yang diatas KKM sebanyak 17 siswa dan pada akhir siklus II bertambah menjadi 22 siswa. Nilai rata-rata kelas meningkat menjadi 84,13.

Peneliti dapat menyimpulkan dengan adanya pembelajaran dengan menggunakan Number Head Together (NHT) kelompok kecil mampu meningkatkan hasil belajar siswa untuk menyelesaikan soal cerita sesuai dengan kriteria ketuntasan belajar klasikal yaitu $\geq$ $80 \%$. Kekurangan pada siklus I sudah mengalami perubahan yang signifikan dan mengalami perbaikan menjadi lebih

baik. Hal itu ditunjukkan dengan nilai rata-rata dalam menyelesaikan soal cerita mengalami peningkatan menjadi 84,13. Nilai rata-rata tersebut sudah memenuhi kriteria ketuntasan belajar pada siklus II yang merupakan siklus terakhir pada Penelitian tindakan kelas ini.

\section{KESIMPULAN}

Berdasarkan hasil perbaikan pembelajaran untuk meningkatkan kemampuan menyelesaikan soal cerita menggunakan model Number Head Together (NHT) pada siswa kelas IV SDN banyuajuh 05 kamal yang telah dilaksanakan, hasil siklus I mencapai ketuntasan klasikal $70,83 \%$ dan mengalami peningkatan yang signifikan hingga mencapai ketuntasan klasikal 91,67 \% pada siklus II. Jadi dapat disimpulkan adanya peningkatan hasil belajar secara klasikal dari siklus I ke siklus II dalam pembelajaran Matematika materi menyelesaikan soal cerita pecahan menggunakan strategi Number Head Together (NHT). Keterlibatan siswa secara aktif dalam kelompok pada pembelajaran Matematika dengan strategi Number Head Together (NHT) membantu siswa untuk memecahkan dan mengatasi kesulitan-kesulitan dalam menyikapi mata pelajaran yang dihadapi. Dengan mengunakan strategi Number Head
Together (NHT), siswa lebih dapat meningkatkan prestasi belajarnya dalam menanggapi materi dan permasalahan belajarnya untuk mendapatkan hasil lebih optimal

Berdasarkan penelitian yang telah dilakukan dan simpulan diatas, maka saran peneliti adalah sebagai berikut:

1. Strategi Number Head Together (NHT) dapat meningkatkan prestasi belajar siswa, maka sebaiknya digunakan pada bidang matematika dengan materi pembahasan yang lainnya ataupun pada bidang studi yang lainnya.

2. Mengingat pelaksanaan penelitian ini hanya berjalan dua siklus maka peneliti berharap agar peneliti lain dapat melanjutkan penelitian ini untuk memperoleh temuan yang lebih signifikan.

3. Penelitian ini jauh dari kesempurnaan dan tak luput dari kesalahan, maka peneliti berharap adanya kritikan dan saran yang membangun dari pembaca guna mencapai hasil penelitian yang lebih baik lagi.

4. Sekolah dengan karakter yang sama dapat menerapkan strategi Number Head Together (NHT) dalam pembelajaran matematika terutama dalam penyelesaian soal cerita.

\section{Saran}

Saran yang diberikan penulis, sebaiknya pembelajaran dengan memanfaatkan media berita televisi dilaksanakan pada pelajaran Bahasa Indonesia khususnya kegiatan berbicara dengan kompetensi dasar yang berbeda agar siswa lebih meningkatkan kemampuan berbicara. Selain itu mengingat pada penelitian ini masih terdapat kekurangan, diantaranya ada siswa yang belum mengalami peningkatan keterampilan berbicara, maka saran bagi peneliti selanjutnya supaya mengkombinasikan dengan penggunaan 
metode pembelajaran lain yang lebih meningkatkan hasil belajar siswa.

relevan yang sekiranya dapat

\section{DAFTAR PUSTAKA}

Arikunto, Suharsimi. 2009. Penelitian Tindakan Kelas. Jakarta: Bumi Aksara.

Arikunto,Suharsimi. 2006. Prosedur Penelitian Satuan Pendekatan Praktik. Jakarta: Rineka Cipta.

Hamadi, Abu. 2004. Psikologi Belajar. Jakarta : Rineka Cipta.

Hamalik, Oemar. 2007. Proses Belajar Mengajar. Jakarta: Bumi Aksara.

Haris, Jihad. 2010. Evaluasi Pembelajaran.Yogyakarta: Multi Pressindo.

Herdian. 2009. Model Pembelajaran NHT. Diakses pada tanggal 21 Maret 2014, dari http://herdy07.wordpress.com/2009/04/22/model-pembelajaran-nht-numberedhead-together/.

Lie, Anita. 2002. Kooperatif Learning. Jakarta: Gramedia Widya Sarana Indonesia.

Marzuki. 1983. Metodologi Riset. Yogyakarta: UII Yogyakarta.

Muhaimin. 1996. Strategi belajar Mengajar. Surabaya: CV Citra Media.

Nasution. 2003. Metodologi Research Penelitian Ilmiah. Jakarta: Bumi Aksara.

PGMI, Lapis. 2004. Strategi Pembelajaran. Surabaya: Aprinta.

PGMI, Lapis. 2004. Penelitian Tindakan Kelas. Surabaya: Aprinta.

PGMI, Lapis. 2004. Pembelajaran Matematika MI. Surabaya: Aprinta.

PGMI, Lapis. 2004. Matematika 1. Surabaya: Aprinta.

Purwanto. 2010. Evaluasi Hasil Belajar. Yogyakarta: Pustaka Belajar.

Sardiman. 2001. Interaksi dan Motivasi Belajar Mengajar. Jakarta: PT. Raja Grafindo Persada.

Sugiyono. 2010. Metode Penelitian Pendidikan. Bandung: Alfabeta.

Sudjana, Nana. 2000. Dasar-dasar Proses Belajar Mengajar. Bandung: PT Sinar Baru Algensindo.

Damayanti, Taulia. 2012. Penerapan Model Pembelajaran Kooperatif Tipe Numbered Heads Together (NHT) dalam Meningkatkan Hasil Belajar Mata Pelajaran Matematika pada Siswa SMA. Diakses 12 Maret 2014, dari http://taulia.wordpress.com/2012/01/21/numbered-heads-together/.

Raharjo, Marsudi. 2009. Pembelajaran Soal Cerita di SD. Yogyakarta: Pusat Pengembangan dan Pemberdayaan Pendidikan dan Tenaga Kependidikan. 
Uno, Hamzah B. 2011. Model pembelajaran. Jakarta: Bumi Aksara.

Wabula. 2013. Model Pembelajaran Number Head Together. Diakses 12 Maret 2014, dari http://wabula.wordpress.com/2013/05/13/number-head-together/ 
